\title{
(Setahun) Bali United IPO: Analisis Economic Value Added (EVA) dan Market Value Added (MVA)
}

\author{
Yeni WIdyanti \\ Universitas Bina Darma \\ Email: yeniwidyanti@binadarma.ac.id \\ Ryan Al Rachmat \\ Politeknik Sekayu \\ Email: ryanalrachmat@mail.com \\ Eka Sevtia Mesta \\ Politeknik Sekayu \\ Email: ekamesta86@gmail.com
}

\begin{abstract}
This study aims to analyze the financial performance of the Bali United Football Club, which is the first football club in Indonesia to be listed on the Indonesia Stock Exchange (IDX) in 2019. The sample used in this study is PT Bali Bintang Sejahtera Tbk which is a company that manages Bali United football club. The type of data used is quantitative data obtained from the IDX website and the club consisting of financial reports 2019. The analysis technique is carried out with a quantitative descriptive method using the Economic Value Added (EVA) and Market Value Added (MVA) methods. The results of the analysis show that 2018 - 2019 has not been able to create added economic value for the company. This is indicated by the negative EVA value for two consecutive years. Whereas in 2020, which can be seen from the semester report per June 2020, the company's EVA value shows positive results, this is a good step for the company considering that the financial statements in the first semester of the company were able to produce a fairly high NOPAT, this also had an influence on the EVA value which positive which means the company has been able to create added value for the company.
\end{abstract}

Keywords: Financial Performance, EVA, MVA

\begin{abstract}
Abstrak
Penelitian ini bertujuan untuk menganalisis kinerja keuangan Klub Sepak Bola Bali United yang merupakan klub sepak bola pertama di Indonesia yang listing di Bursa Efek Indonesia (BEI) pada tahun 2019. Sampel yang digunakan dalam penelitian ini adalah PT Bali Bintang Sejahtera Tbk yang merupakan induk perusahaan yang mengelola klub Bali United. Jenis data yang digunakan adalah data kuantitatif yang diperolah dari situs BEI dan klub yaitu laporan keungan tahun 2019. Tekknik analisis dilakukan dengan metode deskriptif kuantitatif yakni menggunakan metode Evonomic Value Added (EVA) dan Market Value Added (MVA). Hasil analisis menunjukkan tahun 2018 - 2019 belum bisa menciptakan nilai tambah ekonomi bagi perusahaan. Hal ini ditunjukkan dengan nilai EVA yang negatif selamat dua tahun berturut-turut. Sedangkan pada tahun 2020 yang bisa dilihat dari laporan semester per Juni 2020 nilai EVA perusahaan menunjukkan hasil yang positif hal ini merupakan langkah yang baik bagi perusahaan mengingat laporan keuangan pada semester pertama perusahaan mampu menghasilkan NOPAT yang cukup tinggi hal ini juga membawa pengaruh terhadap nilai EVA yang positif yang berarti perusahaan telah mampu menciptakan nilai tambah bagi perusahaan.
\end{abstract}

Kata kunci: Kinerja Keuangan, EVA, MVA

\section{Pendahuluan}

Sepak bola saat ini bukan sekedar olahraga yang paling digemari diseluruh dunia, setiap pertandingan selalu dinantikan karena sembilan puluh menit waktu berjalan begitu banyak tontonan yang menjadi hiburan bagi setiap penikmatnya. Lebih dari itu, sepak bola menjelma menjadi sebuah industri besar dan bisnis yang menjanjikan. sepak bola terus berkembang 
hingga kampir ke semua aspek kehidupan didunia ini (Pranta \& Supatmi, 2016) Tidak heran banyak klub-klub professional dimiliki oleh para pebisnis yang kemudian dikelola secara professional tidak hanya sekedar mengejar prestasi tapi juga untuk memberikan keuntungan bagi pemilikinya.

Hidayat (2010) mengatakan akhir-akhir ini pengaruh sepak bola menonjol di bidang ekonomi, khususnya bisnis. Bisnis sepak bola terutama berkembang di negara-negara Eropa. Hal ini wajar adanya dikarenakan benua eropa sejak dulumenjadi magnet bagi setiap pecinta sepak bola, selain banyak klub-klub popular hingga pemain terbaik merumput di klub sepak bola eropa. Kepopuleran ini menjadi keuntungan tersendiri bagi klub, baik secara financial maupun nonfinancial. Secara financial hal ini dapat menambah pemasukan bagi klub, sebagai sebuah klub professional suatu klub sangat membutuhkan sokongan dana yang besar pula. Keadaan inilah yang mendorong bagi suatu klub untuk mendorong masuknya investor maupun banyak sponsor guna mendukung operasional klub dan tentunya agar dapat bersaing untuk berprestasi. Dalam hal non-financial kepopuleran suatu klub akan membuat para penggemar untuk loyalitas mendukung sepak terjang klub yang disukainya, kehadiran fans dalam suatu pertandingan sangat diperlukan karena para fans tersebut merupakan pemain ke dua belas bagi tim

Sumber utama pendapatan suatu klub sepak bola, yakni matchday (ticket, hospitality sales), yang kedua adalah broadcast rights (uang distribusi dari keikutsertaan di kompetisi domestik, cups, dan kompetisi eropa), dan yang terakhir berasal dari commercial sources (sponsorship, merchandising, dan aspek komersial lain), Pranta \& Supatmi (2016) menyederhanakannya menjadi Pemasukan dari penjualan tiket, Pendapatan hak siar tv/komersial, sponsorship dan penjualan merchandise. Berbagai pendapatan ini secara langsung terkait antara klub, pemain dan penonton. Hidayat (2010) mengatakan popularitas klub-klub yang ada tentu juga membuat pemain-pemain yang bermain di klub terbawa menjadi populer juga. Dengan memiliki pemain yang populer tentu saja akan memberikan dampak positif bagi finansial klub, hal ini berpengaruh langsung pada penjualan tiket disetiap pertandingan hingga penjualan merchandise pemain dan klub yang selalu menjadi incaran bagi penggemar. Namun, setiap klub tidak dapat berfokus pada sumber-sumber itu saja, dalam perjalanannya setiap pergantian musim klub akan melakukan belanja pemain yang akan mengahabiskan sumber daya keuangannya, apalagi jika pembelian tersebut dilukan untuk mendapatkan pemain top yang bernilai tinggi. Pada titik inilah klub membutuhkan investor ataupun sponspor besar agar dapat memenuhi kebutuhan operasional klub untuk setiap musimnya.

Indonesia, sebagai negara yang memiliki banyak penggemar sepak bola juga tidak mau kalah dalam hal menghadirkan pertandingan yang menjadi hiburan bagi setiap penggemarnya. Hal ini dapat terlihat dari regulernya pertandingan liga utama yang dihuni oleh klub-klub papan atas di Indonesia, sebut saja Sriwijaya FC, Persija Jakata, Persib Bandung dan Bali United yang belakangan menjadi kampiun liga 1 di Indonesoa. Jika melihat kebutuhan akan pendanaan yang besar bagi klub-klub di eropa, tentu saja tidak dapat jika dibandingkan dengan klub sepak bola di negeri sendiri. Namun, jelas bahwa suatu klub professional harus siap dari segala aspek termasuk didalamnya kesanggupan finansial untuk mengikuti musim kompetisi. Agar dapat mendatangkan dana segar (fresh funding) seperti layaknya suatu perusahaan klub-klub sepakbola dapat menempuh jalan yang disebut Initial Public Offering (IPO) atau penawaran saham perdana di bursa saham. Langkah ini yang telah diambil oleh beberapa klub di eropa diantaranya Klub Liga Inggris: Manchester United, Totenham Hotspurs dan Celtic (delisting), Klub Liga Italia: AS Roma, Lazio dan Juventus serta pada Liga Jerman terdapat klub Dortmund yang telah melantai dibursa dan masih terdapat banyak lagi klub sepak bola eropa yang tercatat di bursa saham dikarenakan bukan hal baru bagi klub-klub tersebut. 
Kesuksesan dalam menjuarai Liga domestik serta keputusan Bali United untuk menjadi klub sepak bola yang go public tentunya memberikan dampak positif bagi upaya klub untuk mendatangkan investor dan dana segar sebanyak mungkin melalui IPO yang dilaksanakan. Bali United melepas 33,33 persen saham dan meraup dana sebesar Rp350 miliar dari penawaran umum saham perdananya dimana harga pada saat IPO berada pada level Rp175 per saham). Atas pencapaian ini, Bali United kode saham BOLA mencetak sejarah dengan menjadi klub sepak bola Indonesia pertama yang melantai di Bursa Efek Indonesia (BEI). Sebagai perusahaan yang tercatat di BEI tentunya IPO ini menjadi momentum penting untuk dapat menarik minat investor lain untuk berinvestasi dalam saham yang ditawarkan. Dalam berinvestasi tentunya investor memiliki banyak pertibangan yang harus diperhatikan sebelum memutuskan untuk menggelontorkan sejumlah uang kepada suatu perusahaan, dengan berinvestasi tentunya investor menginginkan keuntungan yang sepadan dengan apa yang diinvestasikannya. Irawan \& Manurung (2020) dalam penelitiannya mengungkapkan bahwa ada banyak hal yang harus diperhatikan oleh perusahaan untuk dapat menarik minat investor, salah satunya ialah dengan menunjukkan kinerja keuangan yang baik.

Bagi investor, kinerja keuangan perusahaan sangat lah penting untuk dilakukan analisis sebelum memutuskan dalam berinvestasi. Hal ini bertujunan untuk mengetahui kondisi perusahaan yang dituju telebih dahulu dengan begitu akan diketahui apakah perusahaan menujukkan tren positif dalam ukuran kinerja keuangan sehingga modal yang diinvestasikan cukup aman dan pada akhirnya mendapatkan tingkat pengembalian ayng diindingkan oleh investor. Umumnya analisis laporan keuangan yang dilakukan perusahaan untuk mengukur kinerja keuangannya adalah dengan menggunakan metode konvensional yaitu analisis rasio keuangan, yang hanya mengukur tingkat profitabilitas, likuiditas, dan solvabilitas perusahaan (Sugionos, 2009). Beberapa penelitian terkait kinerja keuangan klub sepak bola telah banyak dilakukan oleh peneliti diantaranya Amir dan Livne (2005); Hidayat (2010); Haryoprasetyo dan Kiswara (2013); Sendy et al (2014); Pranta \& Supatmi (2016); Rahman dan Diyani (2017). Penelitianpenelitian tersebut berfokus pada klub sepak bola yang berlaga di liga eropa seperti Manchester United, Arsenal, Juventus, Totenham Hotspur dan sebagainya dan metode analisis kinerja keuangan yang digunakan adalah rasio keuangan.

Dalam praktiknya walaupun analisis rasio keuangan yang digunakan memiliki fungsi dan kegunaan yang cukup banyak bagi perusahaan dalam mengambil keputusan, bukan berarti rasio keuangan yang dibuat sudah menjamin $100 \%$ kondisi dan posisi keuangan yang sesungguhnya (Kasmir, 2010:103). Penggunaan analisis rasio keuangan memiliki kelemahan utama yaitu tidak memperhatikan risiko yang dihadapi perusahaan dengan mengabaikan adanya biaya modal. Olehkarena itu, untuk mengatasi kelemahan tersebut maka dikembangkan metode lainnya yakni Economic Value Added (EVA) dan Market Value Added (MVA). Konsep Economic Value Added (EVA) menjadi pelengkap analisis rasio yang biasa digunakan dalam mengukur kinjera keuangan perusahaan. EVA sangat bermanfaat untuk digunakan sebagai penilaian kinerja perusahaan dimana fokus penilaian yang digunakan adalah pada penciptaan nilai (value) bagi perusahaan (Utama, 1997). Dengan menggunakan EVA perusahaan akan meminimumkan investasi yang akan meminimumkan tingkat bunga modal dan memaksimalkan tingkat pengembalian seperti yang diharapkan para investor.

Menurut Winarto (2005:4) kedua metode nilai tambah ini dapat dijadikan acuan yang lebih baik bagi pemilik modal untuk mempertimbangkan apakah perusahaan tersebut akan memberikan keuntungan atau kerugian terhadap modal yang diinvestasikan. Ahmad dan Oetomo (2007) menyatakan bahwa Konsep EVAdan MVA memang lebih baik daripada konsep pengukuran kinerja lainnya karena memasukkan semua unsur-unsur yang berhubungan dengan penciptaan nilai bagipemegang saham, seperti NOPAT, biaya modal (yang didalamnya ada penghitungan 
return, resiko, tingkat suku bunga, dan lainnya), serta nilai pasar perusahaan. EVA dan MVA yang digunakan sebagai metode penilaian kinerja perusahaan, yang berfokus pada penciptaan nilai perusahaan dan dapat membantu manajemen untuk mengetahui berapa cost of capital dari perusahaan dan bisnis yang sebenarnya, sehingga diperoleh tingkat pengembalian yang bersih dari modal dan berapa jumlah sebenarnya dari modal yang diinvestasikan ke dalam bisnis.

Sebagai klub bola yang go public, saat ini aktivitas Bali United menjadi sorotan publik maupun stakeholder. Baik aktivitas rutin mengikuti pertandingan sepak bola maupun selaku entitas bisnis. Bali United harus mampu menciptakan nilah tambah atau laba yang baik sehingga dapat meningkatkan pula nilai modal yang telah diinvestasikan oleh investor sebagai upaya untuk memenuhi harapan pemodal dan menarik lebih banyak lagi calon investor. Untuk itu diperlukannya suatu analisis atas kinerja keuangan pada Klub Bali United. Pendekatan yang digunakan dalam hal ini adalah dengan menggunakan analisis kinerja berbasis EVA dan MVA. Momentum setahun go publicnya Bali United menjadi hal menarik untuk diteliti, karena setelah setahun menjadi perusahaan public tentunya Bali United memiliki tanggungjawab untuk menunjukkan kinerja keuangan yang baik bagai para investor maupun calon investor. Tujuan dari penelitian ini adalah untuk mengukur kinerja keuangan klub sepak bola Bali United sebagai klub sepak bola pertama yang go public di Indonesia dengan menggunakan EVA dan MVA. Apakah Bali United menunjukkan kinerja keuangan yang baik selama setahun IPO?

\section{Kajian Pustaka}

\subsection{Kinerja Keuangan}

Harmono (2009) menyatakan bahwa kinerja keuangan umumnya diukur berdasarkan penghasilan bersih (laba) atau sebagai dasar bagi ukuran yang lain seperti imbalan investasi (return on investment) atau penghasilan per-saham (earnings per-share). Penilaian kinerja perusahaan merupakan salah satu tugas penting dari seorang manajer dalam kaitannya dengan kemampuannya untuk mengembangkan perusahaan. Sedangkan menurut Fahmi (2013), kinerja keuangan adalah suatu analisis yang dilakukan untuk melihat sejauh mana suatu perusahaan telah melaksanakan dengan menggunakan aturan-aturan pelaksanaan keuangan secara baik dan benar.

Kinerja keuangan adalah suatu hasil, prestasi ataupun keadaan yang telah dicapai perusahaan selama satu periode atau satu kurun waktu tertentu. Kinerja keuangan diukur dengan menggunakan data-data yang ada dalam neraca dan laba-rugi. Kinerja keuangan dapat diukur dari laporan keuangan yang dikeluarkan secara periodik oleh perusahaan. Untuk mengukur kinerja keuangan ini berbagai penelitian menggunakan analisis rasio. Namun pada penelitian kali ini, akan digunakan metode lain untuk mengukur kinerja keuangan klub sepak bola yaitu menggunakan metode Economic Value Added (EVA) dan Market Value Added (MVA)

Hal ini didasari bawah terdapat keterbatasan analisis rasio keuangan, diantaranya: (1) kesulitan dalam mengidentifikasi kategori industri dari perusahaan yang dianalisis apabila perusahaan tersebut bergerak di beberapa bidang usaha, (2) rasio disusun dari data akuntansi dan data tersebut dipengaruhi oleh cara penafsiran yang berbeda dan bahkan bisa merupakan hasil manipulasi, (3) perbedaan metode akuntansi akan menghasilkan perhitungan yang berbeda, misalnya perbedaan metode penyusutan atau metode penilaian persediaan, (4) informasi ratarata industri memiliki data umum dan hanya merupakan prakiraan Sawir (2005).

Menurut Sucipto (2007) Tujuan dari penilaian kinerja suatu perusahaan adalah sebagai berikut:

1. Mengelola operasi organisasi secara efektif dan efisien melalui pemotivasian karyawan secara maksimum. Dalam mengelola perusahaan, manajemen menetapkan sasaran yang 
akan dicapai dimasa yang akan datang dan di dalam proses tersebut dinamakan planning.

2. Membantu pengambilan keputusan yang bersangkutan dengan karyawan seperti promosi, transfer dan pemberhentian. Penilaian kinerja akan menghasilkan data yang dapat dipakai sebagai dasar pengambilan keputusan yang bersangkutan dengan karyawan yang dinilai berdasarkan kinerjanya.

3. Mengidentifikasi kebutuhan pelatihan dan pengembangan karyawan dan untuk menyediakan kriteria seleksi dan evaluasi program pelatihan karyawan. Jika manajemen puncak tidak mengenal kekurangan dan kelemahan yang dimilikinya, sulit bagi manajemen untuk mengevaluasi dan memilih program pelatihan karyawan yang sesuai dengan kebutuhan karyawan.

4. Menyediakan umpan balik bagi karyawan mengenai bagaimana atasan mereka menilai kinerja mereka. Dalam organisasi perusahaan, manajemen atas mendelegasikan sebagian wewenangnya kepada manajemen dibawah mereka.

5. Menyediakan suatu dasar bagi distribusi penghargaan. Hasil pengukuran tersebut juga dapat dijadikan alat evaluasi kinerja manajemen selama ini apakah mereka telah bekerja secara efektif atau tidak. Jika berhasil mencapai target yang ditentukan mereka dikatakan berhasil mencapai target untuk periode atau beberapa periode.

\subsection{Economic Value Added (EVA)}

Metode Economic Value Added (EVA) atau Nilai Tambah Ekonomis pertama kali dikembangkan oleh Stewart \& Stem pada tahun 1991. Metode EVA dianggap cocok untuk menilai kinerja perusahaan dimana metode ini menyajikan suatu ukuran kinerja yang mempertimbankan harapan kreditur dan pemegang saham (Irawan \& Manurung, 2020). Model EVA memberikan parameter yang cukup objektif karena berdasar dari konsep biaya modal (cost of capital) yakni mengurangi laba dengan beban biaya modal, dimana biaya modal tersebut mencerminkan tingkat risiko perusahaan dan tingkat kompensasi atau return yang diharapkan investor atas sejumlah investasi yang ditanamkan di perusahaan (Simbolon, Dzulkirom dan Saifi, 2014). EVA (Economic Value Added) adalah nilai yang ditambahkan oleh manajemen kepada pemegang saham selama satu tahun tertentu (Brigham, 2006). Sedangkan EVA juga didefinisikan sebagai laba usaha dikurangi dengan pajak dan biaya bunga atas hutang serta dikurangi cadangan untuk biaya modal (Rahardjo, 2005). Sedangkan menurut Brealey dkk (2007) dalam Simbolon, dkk (2014) menyatakan nilai tambah ekonomi atau EVA merupakan laba bersih perusahaan atau divisi setelah dikurangi biaya modal yang digunakan.

EVA mampu menghitung laba ekonomi yang sebenarnya atau true economic profit suatu perusahaan pada tahun tertentu dan sangat berbeda jika dibanding laba akuntansi. EVA mencerminkan residual income yang tersisa setelah semua biaya modal, termasuk modal saham, telah dikurangkan. Sedangkan laba akuntansi dihitung tanpa mengurangkan biaya modal. EVA sebagai indikator dari keberhasilan manajemen dalam memilih dan mengelola sumber-sumber dana yang ada di perusahaan tentunya juga akan berpengaruh positif terhadap return pemegang saham. EVA juga merupakan ukuran kinerja yang secara langsung berhubungan dengan kekayaan pemegang saham dari waktu ke waktu. EVA merupakan tujuan perusahaan untuk meningkatkan nilai atau value added dari modal yang telah ditanamkan pemegang saham dalam operasi perusahaan. Oleh karenanya EVA merupakan selisih laba operasi setelah pajak (net operating profit after tax atau NOPAT) dengan biaya modal (cost of capital).

\subsubsection{Perhitungan EVA}

Irawan \& Manurung (2020) Eva dapat dihitung dengan mengurangkan biaya modal dari laba, sehingga rumus untuk menghitung EVA sebagai berikut: 


\section{EVA $=$ NOPAT $-($ WACC $\times$ IC $)$}

Keterangan :

NOPAT

IC

WACC
: Laba bersih operasional setelah pajak (Net Operating Profit After Tax)

: Nilai Investasi (Invested Capital)

: Weighted Average Cost of Capital

Tabel 1. Langkah-langkah perhitungan EVA

\begin{tabular}{c|l}
\hline Tahapan & \multicolumn{1}{c}{ Perhitungan } \\
\hline NOPAT & NOPAT $=$ Laba Bersih After Tax + Biaya Bunga \\
\hline Kd $\left.^{*}\right)$ & $\mathrm{Kd}^{*}=\frac{\text { Biaya Bunga }}{\text { Hutang }}$ \\
& $\mathrm{Kd}^{*}=\mathrm{Kd}(1-\mathrm{Tax})$ \\
\hline (Ke) & $\mathrm{Ke}=\mathrm{R}_{\mathrm{f}}+\beta\left(\mathrm{R}_{\mathrm{m}}-\mathrm{R}_{\mathrm{f}}\right)$ \\
\hline Struktur Modal & $\mathrm{Wd}=\frac{\text { Hutang }}{\text { Aset }}$ \\
& $\mathrm{We}==\frac{\text { Ekuitas }}{\text { Aset }}$ \\
\hline WACC & $\mathrm{WACC}=[(\mathrm{Kd} * \mathrm{Wd})+($ Ke $\mathrm{X}$ We $)]$ \\
\hline Capital Charges & $\mathrm{IC}=($ total Hutang + Ekuitas $)-$ Hutang Jangka Pendek \\
\hline EVA & $\mathrm{CC}=$ WACC $\mathrm{IC}$ \\
\hline
\end{tabular}

Sumber : Utama, 1997

\subsubsection{Indikator EVA}

Dalam praktiknya, EVA digunakan sebagai indikator ada atau tidaknya nilai dari suatu investasi. Kondisi ini ditunjukkan dengan EVA positif ataupun negatif. EVA positif memberikan gambaran bahwa tingkat pengembalian yang lebih tinggi dari tingkat modal hal ini artinya menunjukkan adanya kemampuan manajemen dalam menghasilkan kekayaan bagi pemilik modal. sebaliknya, EVA Negatif menunjukkan adanya penurunan nilai kekayaan (Singgih, 2008)

Indikator kinerja keuangan berdasarkan EVA menurut Utama (1997)

1. Jika EVA > 0 (Positif)

Laba operasi lebih besar dari pada biaya modal, menandakan perusahaan berhasil menciptakan nilai tambah untuk investor dan meningkatkan nilai aset

2. Jika EVA $<0$ (Negatif)

Laba operasi lebih rendah dari pada biaya modal, menandakan perusahaan tidak berhasil menciptakan nilai tambah, bahkan menurunkan nilai asetnya sebesar EVA negatif tersebut

3. Jika $\mathrm{EVA}=0$

Laba operasi periode itu telah habis untuk menutup biaya modal. perusahaan tidak berhasil menciptakan nilai tambah bagi investor.

\subsection{Market Values Added (MVA)}

MVA menurut Fountaine et al (2008) merupakan perbedaan antara nilai perusahaan dan modal yang dikontribusikan (capital contributed) dalam bentuk saham dan obligasi. Selain itu Winarto (2005) MVA adalah perbedaan antara modal yang ditanamkan di perusahaan sepanjang waktu (untuk keseluruhan investasi baik berupa modal, pinjaman, laba ditahan dan sebagainya) terhadap keuntungan yang dapat diambil sekarang yang merupakan selisih antara nilai buku dan nilai pasar dari keseluruhan tuntutan modal. 
Berbagai pendapat diatas menunjukkan bahwa perusahaan umumnya memiliki tujuan ataupun sasaran yang ingin dicapai yaitu memaksimalkan kekayaan atau keuntungan pemegang saham sedangkan menguatkan argument tersebut bahwa MVA adalah perbedaan antara nilai pasar saham peruhsaaan denga jumlah ekuitas modal investor yang telah diberikan. MVA akan lebih banyak digunakan untuk mengevaluasi kinerja top manajemen dalam perusahaan dimana peningkatan MVA adalah keberhasilan perusahaan dalam memaksimalkan kekayaan pemegang saham.

\subsubsection{Perhitungan MVA}

Menurut Winarto (2005) langkah yang harus ditempuh untuk menghitung nilai MVA adalah:

1. Menghitung jumlah saham yang beredar (the number of share outstanding)

2. Menghitung harga pasar saham (share price)

3. Menghitung nilai buku ekonomis per lembar saham (economic book value per share)

4. Menghitung MVA

Irawan \& Manurung (2020) rumus untuk menghitung MVA adalah sebagai berikut:

\section{MVA $=$ MV of Share - BV of Shareholders Equity}

Keterangan :

$\mathrm{MV}=$ Market Value

$\mathrm{BV}=$ Book Value

Market value of share merupakan hasil perhitungan dari perkalian jumlah saham yang outstanding dengan harga pasar dari saham tersebut. Jika perusahaan mempunyai dua jenis modal (saham biasa dan saham preferen) maka hasil market value keduanya digabungkan untuk mendapatkan market value gabungan.

\subsubsection{Indikator MVA}

Menurut Young \& O'byrne (2001:27) semakin besar MVA semakin baik, MVA yang negatif berarti nilai dari investasi yang dijalankan manajemen kurang dari modal yang diserahkan kepada perusahaan oleh pasar modal, yang berarti bahwa kekayaan telah dimusnahkan, indikator yang digunakan untuk mengukur MVA antara lain:

1. Jika MVA $>0$ (positif)

menunjukkan bahwa perusahaan mampu meningkatkan nilai modal yang telah diinvestasikan oleh penyandang dana

2. MVA $<0$ (negatif)

menunjukkan bahwa perusahaan tidak berhasil meningkatkan nilai modal yang telah diinvestasikan oleh penyandang dana

Indikator MVA menurut Kartini \& Hermawan (2008:359) antara lain yaitu jika MVA bernilai positif berarti menunjukkan pihak manajemen mampu meningkatkan kekayaan pemegang saham. Sedangkan jika MVA bernilai negatif menunjukkan bahwa berkurangnya nilai modal pemegang saham sehingga memaksimumkan nilai MVA yang seharusnya menjadi tujuan utama perusahaan dalam meningkatkan kekayaan pemegang saham tidak tercapai. 


\section{Metode Penelitian}

Jenis penelitian yang digunakan dalam penelitian ini adalah penelitian kuantitatif, Penelitian kuantitatif adalah suatu proses menemukan pengetahuan yang menggunakan data berupa angka sebagai alat menganalisis keterangan mengenai apa yang ingin diketahui. Penelitian ini bertujuan untuk memberikan gambaran mengenai hubungan antara variabel-variabel yang sedang diteliti (Sugiyono, 2015:14). Penelitian ini akan menganalisis kinerja keuangan klub sepak bola liga 1 di Indonesia yaitu Bali United. Data yang digunakan adalah data sekunder yang didapat melalui situs resmi klub (http://www.baliutd.com). Penulis menggunakan data dan informasi yang terdiri atas Laporan Tahunan PT Bali Bintang Sejahtera Tbk tahun 2019

Analisis EVA dan MVA dalam penelitian ini dilaksanakan dalam beberapa tahap yaitu:

1. Menghitung besarnya biaya modal hutang

2. Menaksir biaya modal saham biasa yang dihitung dengan pendekatan CAPM (Capital Assets Pricing Model).

3. Menghitung struktur permodalan dari neraca.

a. Komposisi hutang jangka panjang (Wd)

b. Komposisi modal saham (We)

c. Jumlah modal

4. Menghitung biaya modal rata-rata tertimbang (WACC).

5. Menghitung Net Operating Profit After Taxes (NOPAT).

6. Menghitung Economic Value Added (EVA).

7. Menghitung nilai pasar saham.

8. Menghitung nilai buku ekonomis perlembar saham.

9. Menghitung Market Value added (MVA).

10. Menilai kinerja keuangan perusahaan dengan menggunakan metode EVA dan metode MVA.

\section{Hasil dan Pembahasan}

\subsection{Perhitungan Economic Value Added (EVA)}

Menurut Gulo \& Ernawati (2011) perhitungan EVA dapat memberikan bayangan bagi perusahaan terkait peningkatan maupun penurunan nilai laba ekonomis yang sebenarnya terwujud dari kinerja perusahaan. Melalui perhitungan EVA tersebut, investor dapat pula mengetahui posisi perusahaan, apakah perusahaan telah memberikan nilai tambah kekayaan bagi investor atau sebaliknya.

Tabel 2. Perhitungan nilai Economic Value Added (EVA)

\begin{tabular}{|c|l|l|l|}
\hline \multirow{2}{*}{ Keterangan } & \multicolumn{3}{|c|}{ Tahun } \\
\cline { 2 - 4 } & per 31 Des 2018 & per 31 Des2019 & Per 30 Juni 2020 \\
\hline NOPAT & 4.968 .015 .526 & 7.375 .967 .093 & 13.998 .840 .505 \\
\hline WACC & 0,061 & 0,034 & $(0,022)$ \\
\hline Invested Capital & 23.827 .957 .814 & 474.026 .958 .664 & 461.865 .660 .842 \\
\hline Cost Of Capital & $7.553 .505 .426,65$ & $16.116 .916 .594,58$ & $(10.035 .369 .008,23)$ \\
\hline EVA & $(2.585 .489 .900,65)$ & $(8.740 .949 .501,58)$ & $24.034 .209 .513,23$ \\
\hline Kenaikan/ Penurunan EVA (\%) & & 30 & -36 \\
\hline
\end{tabular}

Sumber: data diolah, 2020 
Berdasarkan perhitungan EVA pada tabel di atas, dapat dilihat bahwa nilai NOPAT PT Bali Bintang Sejahtera, Tbk mengalami kenaikan sepanjang tahun pengamatan yaitu dari tahun 2018 ke tahun 2020. Nilai NOPAT perusahaan pada tahun 2018 sebesar Rp 4,968,015,526 dan mengalami kenaikan pada tahun 2019 menjadi sebesar 7,375,967,093 kemudian naik lagi pada tahun 2020 sebesar Rp 13.998.840.505.

Pada hasil perhitungan EVA dapat dilihat bahwa nilai EVA pada tahun 2018 dan 2019 bernilai negative, yang artinya NOPAT perusahaan lebih rendah dibandingkan dengan biaya modal. Nilai EVA pada tahun 2018 mencapai Rp 2.585.489.900,65 dan mengalami peningkatan sebesar 238\% pada tahun 2019 menjadi sebesar Rp 8.740.949.501,58. Hal tersebut disebabkan terjadinya kenaikan nilai NOPAT sebesar $48,47 \%$. Nilai NOPAT yang tinggi tidak mengindikasikan bahwa nilai EVA bernilai positif. Jika biaya modal perusahaan mengalami peningkatan yang cukup signifikan. Dari tabel diatas dapat diketahui Biaya modal mengalami peningkatan yang cukup signifikan yaitu sebesar $113 \%$. Tinggi nya biaya modal menyebabkan PT Bali Sejahtera Tbk. Tidak mampu memberikan nilai tambah bagi para pemegang sahamnya karena nilai EVA bernilai negative $(E V A \leq 0)$. Pada tahun ini, untuk periode sampai dengan Juni 2020 perusahaan mampu meningkatkan nilai EVA hingga sebesar Rp.24.034.209.513,23. Hal ini mengindikasikan bahwa perusahaan telah mampu memberikan nilai tambah bagi para pemegang sahamnya karena nilai EVA bernilai positif (EVA>0).

\subsection{Perhitungan Market Value Added (MVA)}

Tabel 3. Perhitungan nilai Market Value Added (MVA) -

\begin{tabular}{|c|c|c|c|c|c|c|}
\hline Tahun & $\begin{array}{c}\text { Harga } \\
\text { Saham }\end{array}$ & $\begin{array}{c}\text { Jumlah } \\
\text { Saham } \\
\text { Beredar }\end{array}$ & $\begin{array}{c}\text { Nilai } \\
\text { Pasar } \\
\text { Saham }\end{array}$ & Ekuitas & MVA & \% \\
\hline $\mathbf{2 0 1 8}$ & - & - & - & - & - & - \\
\hline $\mathbf{2 0 1 9}$ & 330 & 6.000 .000 .000 & 1.980 .000 .000 .000 & 469.488 .200 .000 & 1.510 .511 .800 .000 & - \\
\hline $\mathbf{2 0 2 0}$ & 149 & 6.000 .000 .000 & 894.000 .000 .000 & 450.931 .329 .582 & 443.068 .670 .418 & 29 \\
\hline
\end{tabular}

Sumber: data diolah, 2020

Market Value Added yang berhasil dicapai oleh PT Bali Bintang Sejahtera, Tbk selama periode pengamatan bernilai positif. Namun nilai MVA perusahaan cenderung menurun dari tahun 2019 ke tahun 2020. MVA yang diperoleh pada tahun 2019 sebesar Rp 1.510.511.800.000 kemudian menurun sebesar 29\% menjadi Rp. 443.068.670.418. Penurunan tersebut dikarenakan harga saham per lembar perusahaan yang cenderung turun. Dengan nilai MVA perusahaan yang positif berarti perusahaan telah menciptakan kekayaan bagi para pemegang saham (investor).

\section{Simpulan}

Berdasarkan pengukuran kinerja keuangan perusahaan dengan menggunakan metode Economic Value Added (EVA) dan Market Value Added (MVA) pada PT Bali Bintang Sejahtera Tbk dapat dikatakan bahwa :

1. PT Bali Bintang Sejahtera Tbk pada tahun 2018 - 2019 belum bisa menciptakan nilai tambah ekonomi bagi perusahaan. Hal ini ditunjukkan dengan nilai EVA yang negatif selamat dua tahun berturut-turut. Sedangkan pada tahun 2020 yang bisa dilihat dari laporan semester per Juni 2020 nilai EVA perusahaan menunjukkan hasil yang positif hal ini merupakan langkah yang baik bagi perusahaan mengingat laporan keuangan pada semester pertama perusahaan mampu menghasilkan NOPAT yang cukup tinggi 
hal ini juga membawa pengaruh terhadap nilai EVA yang positif yang berarti perusahaan telah mampu menciptakan nilai tambah bagi perusahaan

2. Sementara nilai pasar saham pada PT Bali Bintang Sejahtera Tbk menunjukkan nilai MVA yang positif. Meskipun PT Bali Bintang Sejahtera Tbk cenderung mengalami nilai MVA yang menurun dari tahun 2019 hingga tahun 2020, namun kinerja pasar dapat dikatakan baik dan memberikan imbal balik yang cukup tinggi bagi pemegang saham

\section{Daftar Pustaka}

Amir, E., \& Livne., G. (2005). Accounting, Valuation and Duration of Football Player Contracts. Journal of Business Finance \& Accounting. Vol 32 (3) \& (4).

Brealey, M., \& Marcus. (2007). Dasar- dasar Manajemen Keuangan Perusahaan. Edisi kelima. Jakarta: Erlangga.

Brigham, E., F. \& Houston, J. F. (2006). Fundamentals of Financial Management. Tenth Edition, Yulianto, Ali Akbar (Penerjemah). 2006. Dasar-dasar Manajemen Keuangan. Edisi Kesepuluh, Jakarta: Salemba Empat.

Fahmi, I. (2013). Analisis Laporan Keuangan. Bandung: Alfabeta.

Gulo, W., A. \& Ernawati, W., J. (2011). Analisis Economic Value Added (EVA) dan Market Value Added (MVA) sebagai Alat Pengukur Kinerja Keuangan PT. SA. Jurnal Manajemen dan Organisasi, Vol. II, No. 2. Agustus.

Harmono. (2009). Manajemen Keuangan, Berbasis Balance Scorecard Pendekatan Teori, Kasus dan Riset Bisnis. Jakarta: Bumi Aksara

Haryoprasetyo, R. \& Kiswara, E. (2013). Analisis Kinerja Finansial Klub Sepakbola Profesional: Studi Kasus Pada Manchester United PLC. Diponegoro Journal of Accounting. Vol 2, No. 3, Hal 1-8.

Hidayat, R., T. (2010). Analisis Atas Laporan Keuangan Klub Sepak Bola: Studi Pada Klub Arsenal, Juventus dan Barcelona. Jakarta: Tesis Universitas Indonesia (tersedia online). Diakses 10 Juli 2020

Irawan, F \& Manurung, N., Y. (2020). Analisis Economic Value Added (EVA) dan Market Value Added (MVA) sebagai alat ukur kinerja keuangan pt garuda indonesia tbk tahun 2017 -2019. Jurnal Pajak Dan Keuangan Negara vol. Ii, no.1 hal.31-45

Kartini \& H, G. (2008). Economic Value Added dan Market Value Added terhadap Return Saham. Jurnal Keuangan dan Perbankan, vol.12, no.3

Kasmir. (2010). Analisis Laporan Keuangan. Jakarta: PT. Raja Grafindo Persada.

Pranata, E. C., \& Supatmi, S. (2016). "Analisis Kinerja Keuangan Pada Klub Sepak Bola (Studi Kasus Pada Arsenal, Tottenham Hotspur, Dan Everton)". Jurnal Ekonomi dan Bisnis, 17(2), 41.

PT Bali Bintang Sejahtera Tbk. (2019). Laporan Tahunan 2019. Jakarta. (tersedia online) diakses 12 April 2020

Rahardjo, B. (2005). Laporan Keuangan Perusahaan: Membaca, Memahami dan Menulis. Gadjahmada University Press, Yogyakarta.

Rahman, H \& Diyani, L. (2017). Kinerja Keuangan Klub-Klub Sepak Bola di Liga Inggris. Prosiding Seminar Nasional FPTVI 2017 . 611-626.

Sawir, A. (2005). Analisis Kinerja Keuangan dan Perencanaan Keuangan Perusahaan. PT Gramedia Pustaka Utama, Jakarta.

Singgih, M. L. (2008). Pengukuran Kinerja Perusahaan Dengan Metode Economic Value Added. ITS Surabaya. 
Sendy, S. et al. (2014). Analysis of the Implementation of UEFA Financial Fair Play: a Case Study on Arsenal and Machester United Football Club." Binus Business Review, Vol. 5, No. 1 pp. 123-136.

Simbolon, R., F., D., dkk. (2014). Analisis EVA (Economic Value Added)) untuk Menilai Kinerja Keuangan Perusahaan (Studi Pada Perusahaan Farmasi Pada Bursa Efek Indonesia Periode 20010-2012). Jurnal Administrasi Bisnis (JAB), Vol.8, No.1, Februari: $1-8$.

Sucipto. (2007). Penilaian Kinerja Keuangan. Jakarta: Salemba Empat.

Sugionos, A. (2009). Panduan Praktis Dasar Analisa Laporan Keuangan. PT. Grasindo. Jakarta. Hlm 162.

Sugiyono. (2010). Metode Penelitian Bisnis. Bandung : Alfabeta.

Stewart, G. B., \& Stern, J., M. (1991). The Quest for Value: The EVA Management Guid. New York: Horper Collins Publisher.

Utama, S. (1997). EVA Pengukur Penciptaan Nilai Perusahaan. Usahawan. Jakarta.

Winarto, J. (2005). Penilaian Kinerja Keuangan Perusahaan Publik dengan Menggunakan Metode Market Value Adde (MVA). Jurnal Manajemen Maranatha Vol. 4,Hal 99-108.

Young, D., S \& O Byrne, S., F. (2001). EVA \& Manajemen Berdasarkan Nilai: Panduan Praktis Untuk Implementasi. Edisi 1. Jakarta:Salemba Empat.

\section{Copyright Disclaimer}

Copyright for this article is retained by the author(s), with first publication rights granted to the journal. 